Vyacheslav, B. A. ., Fedotova, O. A., Kakurina, M. V., Mikhaleva, G. G., \& Novikova, S. V. (2021). Protection of minor rights in Russia and European Union countries. Linguistics and Culture Review, 5(S3), 950-957. https://doi.org/10.21744/lingcure.v5nS3.1688

\title{
Protection of Minor Rights in Russia and European Union Countries
}

\author{
Bocharov A. Vyacheslav
}

Belgorod National Research University, Belgorod, Russia

Olga A. Fedotova

The Russian State University of Justice, Voronezh, Russia

Marina V. Kakurina

The Russian State University of Justice, Voronezh, Russia

Galia G. Mikhaleva

Perm State University, Bukireva, Russia

\section{Svetlana V. Novikova}

Kuban State Agrarian University, Krasnodar, Russia

\begin{abstract}
The goal of the study is to develop the problem of minor rights and legitimate interest protection theoretically. Discussion: A comprehensive analysis of the system for protection the rights of this category of citizens was carried out to achieve this goal. At the same time, special attention is paid to the basic concepts and approaches used for the implementation of the studied legal relations in Russia and the EU countries. Result: they revealed the features of minor right protection system in the Russian Federation and some EU states.
\end{abstract}

Keywords---custodianship, family law, government agencies, guardianship, juvenile justice, minors, rights protection.

\section{Introduction}

The relevance of the research topic is explained by the obvious disadvantage of minor position in society. Despite the fact that the legislation of any state is aimed to protect the rights and legitimate interests of minors, it is difficult to deny the problem that exists in this area. Indeed, children are the most vulnerable social group. Due to their age, physical and mental immaturity, they cannot defend their rights and protect them in front of anyone independently. Therefore, they need special protection and care.

Linguistics and Culture Review (c) 2021.

Corresponding author: Vyacheslav, B.A.; Email: bocharov_va@bsu.edu.ru

Manuscript submitted: 27 July 2021, Manuscript revised: 18 Oct 2021, Accepted for publication: 09 Nov 2021

950 
It is no less important that in the conditions of modern realities of socio-economic and political instability in the world, there is a steady upward trend in violence against minors. Indeed, every second child is abused in one form or another every year. This is stated in the Worldwide Report on the Prevention of Violence against Children 2020, jointly published by UNESCO, WHO, UNICEF, the UN SecretaryGeneral's Special Representative on Violence against Children and the Partnership to End Violence. To eliminate the existing problems, the system of protecting the rights of children is of particular interest, which includes state authorities, local governments, officials, citizens and their associations, whose activities are aimed at formalizing and improving the measures to support and effectively protect the rights of minors.

The system of bodies protecting the rights of minors is based on the current regulatory framework in its activities. Its basis, both in Russia and abroad, is the UN Convention on the Rights of the Child, which by its norms calls on all participating states to conduct effective international cooperation in order to improve the living conditions of children around the world. In the Russian Federation, the norms of international law that are binding on Russia to implement the system for protecting the rights of minors, the Constitution of the Russian Federation, the Family Code of the Russian Federation, the federal laws "On the basic guarantees of child rights in the Russian Federation", "On custodianship and guardianship," On education", Legislation on the protection of citizen health become the most important ones (Fastelli et al., 2018; Kiss et al., 2021). Besides, the norms on the protection of child rights are also contained in civil, criminal, administrative and other branches of legislation (Cross, 1999; Lee et al., 2013).

Currently, the Decree of the President of Russia on the announcement of the Decade of Childhood in Russia during 2018-2027 (http://publication.pravo.gov.ru) is also very important in the structure of normative regulation of legal relations with minors. The purpose of this Decree is to improve the activities of the state aimed at child right protection. If we talk about European states, then every year they improve their regulatory framework in this area, adopting new legal acts (for example, the Council of Europe Strategy for Ensuring the Child Rights during 2016-2021) (https://www.coe.int). Considering that the European Union defines European values as a key element of deepening political and economic integration, both the developed legal instruments and the standards of the Council of Europe are used in all $28 \mathrm{EU}$ member states (https://www.coe.int).

The problem of protection the rights of minors is of natural interest to Russian (Verstova \& Safonova, 2012; Gavrilov, 2010; Nikolaeva \& Ivanova, 2009) and foreign legal scholars (Dtinkel, 2008; Finley, 2007; Sammers, 2010; https://www.diplomatie.gouv.fr), serving as a subject for scientific discussions, the central link of which is legal measures and mechanisms, used for the protection of children. 


\section{Material and Methods}

The study was based on a dialectical approach to the disclosure of legal phenomena and processes using general scientific (systemic, logical, analysis and synthesis) and specific scientific methods. Russia and the countries of the European Union with the most developed institutions for the protection of the rights and legitimate interests of children (Austria, Germany, France, Finland, Sweden) were selected as focus groups.

\section{Results and Discussion}

The analysis of the system for protecting the rights and interests of minors showed that Europe has formed a single coordinated system for the protection and prevention of juvenile delinquency, as well as for bringing these subjects to responsibility, which is provided by both the common European and national legislation of the countries that are the part of the European Union (Parkhatkyzy \& Apakhaev, 1997). First of all, attention is drawn to the fact that the efforts of all state bodies in this case are interconnected and aimed at solving one strategic task.

Besides, special mechanisms for protection the rights of citizens of this category are of particular interest within the framework of this system. One of these in a number of European countries is a special regulation order "parent patrie", when the state acts as a guardian or a responsible person for minors, protecting them from dangerous behavior and harmful environment (Bartollas, 1997).

We cannot ignore the problem of domestic violence, which is relevant both for Russia and for many European countries. At the same time, it can be said without any exaggeration about the well-coordinated mechanism of the system for the minor right protection in Europe, when law enforcement agencies cooperate with custodianship, guardianship, local government and social work experts (Hamner, 2009; Wright, 2010). They have experience of constant and daily work with the families in difficult and even dangerous situations. It should be noted that the powers of a social worker coincide with the scope of powers granted to police officers: he has the right to interview witnesses, interrogate parents, and send inquiries.

"A social worker has every legal right to impose strict demands on the perpetrators. In Germany, Holland, Great Britain, social work experts are endowed with broad powers (up to the initiation of a criminal case and a petition for the alienation of a child from his/her parents). On this basis, the European Union continues to position itself as the main outpost of the struggle for human rights in the world" (Bartollas, 1997). It should be recognized that juvenile justice can become the basis of the system for minor right protection, both in the Russian Federation and in foreign countries (Grisso et al., 2001).

"Juvenile justice represents a certain group of government and administrative bodies that carry out the activities in relation to minors in order to protect their rights and interests and restore social justice" (Parkhatkyzy \& Apakhaev, 1997). In each state, juvenile justice is organized differently. In Austria, Germany, Spain, 
Portugal, the functions of guardianship courts were combined with the functions of juvenile courts, which brought to the fore the task of minor right judicial protection (Valdés et al., 2011; Scholes et al., 2021).

As for the Russian Federation, the juvenile justice system is still a subject for experimental activity and is not fully operational. This is explained by the lack of an appropriate legislative framework that would allow considering juvenile justice and juvenile court as full subjects (Wasserman et al., 2003). The protection of the rights of underage children has a fairly clear, uniform regulation in the European Union countries. A child is considered as an independent subject of juvenile legal relations. To initiate proceedings and investigate any disputes (civil, family law, criminal, administrative, etc.), it is sufficient to make a statement by any person who has information about the violation of child rights or the violation of law requirements on his/her part (Nugraha et al., 2020; Eshonkulov, 2021). Besides, the legislation stipulates the obligation for some categories (doctors, teachers, social workers) when they establish a violation of child rights.

After the child reaches the age of 14, he has the right to apply to the court independently with an application for recognizing him as emancipated. This may be due to marriage, military service, etc. Such a practice as "divorce" from one's parents or guardians is of particular interest in some European countries. This can happen if a court found the parents to have violated the rights of a child and deprived them of their parental rights.

The appeal to the German system for the protection minor rights suggests that the main authority in this system is the department for youth affairs (Jugendamt). This body may be called differently in each city and region. For example, "Department of Children, Youth and Family", "Department of Youth and Social Education" and the like. But the range of duties of this department officials is approximately the same everywhere and consists in the following: ensuring the process of a child comprehensive development, social assistance to young people, support for a young family, helping parents in difficult life situations, raising children, protecting the violated rights of a child.

German law considers a child "as an independent, responsible and socially capable person." The most important principle enshrined in the German Constitution is "the recognition of child care, his upbringing as a natural right of parents and at the same time their primary duty, the implementation of which is monitored by the state" (Children's rights: international and national laws and practices; Sulakshin et al., 2012). Parents (guardians) are obliged to assist a child in individual and social development, to contribute to the elimination of negative moments of such development, to provide advice and support, to protect the child from threats to well-being and to contribute to the maintenance or creation of positive living conditions for the minor (Zharovska et al., 2021).

"The most important distinguishing feature of the German legal order is the priority of child well-being, which is seen as the only and most important reason for depriving parents of the right to upbringing and custody. Thus, Germany is the only country where parents can be deprived of parental rights, regardless of 
the existence of violation facts concerning child rights, only because the child is in danger (Del Carmen \& Trulson, 2005).

The states of the Scandinavian Peninsula consolidate the unique principles of the legal relationship between parents and children. Thus, "any physical influence on a child is prohibited. The child has the right to receive a certain set of fixed benefits. There is legally no parental authority over children. A minor is an independent person. Parents have only the right to present property claims to their child" (Dtinkel, 2008).

When the rights and interests of a child are violated in a family, it is very often necessary to remove him from the family. Finland and the Kingdom of Sweden are considered the leaders among the countries of the European Union in terms of the number of decisions to remove a child from a family. This decision is made out of court - by a specialized body (administrative commission) in the field of social security.

The fundamental reason for the application of such a measure is the concept "children have the right to demand a lot from their parents, parents may demand only support in old age" (Tsukanov \& Bocharov, 2017). The basis of this ideology finds its official confirmation: "The interests of children should be given primary attention. And in order to understand what exactly are the interests of a child, it is necessary to consider things and phenomena from the point of view of the children themselves, while using their (children) experience and knowledge. Children should be proud of their success in school, college, work, and not that they love their parents" (Del Carmen \& Trulson, 2005). The national legislation of other countries that have their own membership in the European Union also has its own peculiarities of protecting the rights of minors (Dtinkel, 2008; Atabekova et al., 2021; Belyaeva et al., 2017).

If we talk about the system of child right protection in the Russian Federation, then it is implemented through "the activities of state authorities, local governments, officials, citizens and their associations, obliged to comply with the Constitution of the Russian Federation and the laws of our state" (Belyaeva et al., 2017). This includes law enforcement agencies, prosecutor's office, court, custodianship and guardianship authorities, commissions on juvenile affairs, etc. (Baranov et al., 2021).

The above list of state bodies protecting the rights of children can hardly be considered exhaustive, since other bodies, the number of which is constantly growing, can also take part in child right protection at the local level (Rinartha et al., 2018). For example, the Center for Social Assistance to Families and Children, the Center for Psychological and Pedagogical Assistance to the Population, the Center for Emergency Psychological Assistance by Telephone, the Social Rehabilitation Center for Minors, the Center for Assistance to Children Left without Parental Care.

Analyzing the functions and tasks assigned to the authorities, local government, and other authorized bodies that form a system of one chain, it can be concluded that there is an inconsistent focus of their activities. Thus, there is an insufficient 
level of their interagency interaction, which leads to an inappropriate solution of the state level problem, aimed both at preventing the asocial behavior of adolescents and associated with the protection of their legal rights and interests (Verstova \& Safonova, 2012).

Unfortunately, most of the laws that have been adopted so far are aimed at prescribing the role of departments and defining the boundaries of their activities. This led to the strengthening of interdepartmental barriers and potentiated the struggle of the departments for budget funds, while the mechanism of interaction between departments and their responsibility for failure to fulfill the functions assigned to them to protect the rights of a child is not spelled out by law. Thus, at present Russia has no unified agreed system that would be entrusted with solving a set of tasks to protect the interests of persons under the age of 18, the activities of which also included the interaction with specialized judicial authorities considering the materials with the participation of minors.

\section{Conclusions}

Thus, it is important to note that, in accordance with the Convention on Child Rights, states must ensure all rights for every child within their jurisdiction, without any discrimination, regardless of race, color, sex, language, religion, political or other convictions, national, ethnic or social origin, property status, health status and birth of a child, his parents or legal guardians, or any other circumstances (Convention of the Rights of the Child, 1989). To ensure these rights, each state has created its own system of protection, implemented through the activities of certain state bodies and public associations. Studies have shown that the system for protecting the rights of minors is more effective and consistent in European countries than in Russia. Besides, "there are also differences in the powers and competences of public authorities of different states ...". Therefore, the experience of the European Union in the implementation of minor right protection system can be successfully applied in Russia.

We believe that the need to organize high-quality protection of child rights requires further formation and development of juvenile justice system, juvenile courts, juvenile prosecutor's offices and juvenile advocates' offices in Russia as compulsory components that make it possible to solve this problem comprehensively. Thus, the ultimate goal of forming an effective single human rights mechanism for minors in Russia and the EU should be the creation of a system for protection the rights of minors that would meet not only international standards, but above all the interests of children of any state.

\section{References}

Atabekova, A.A., Bukalerova, L.A., Simonova, M.A. (2021). On the adoption of a number of provisions of the Council of Europe Strategy on the Rights of the Child (2016-2021).

Baranov, P. P., Mamychev, A. Y., Dremliuga, R. I., \& Miroshnichenko, O. I. (2021). Legal consciousness and legal culture in the era of total digitalization: Theoretical-methodological and legal-technical problems. Linguistics and 
Culture Review, 5(S3),

899-910.

https:/ / doi.org/10.21744/lingcure.v5nS3.1665

Bartollas, C. (1997). Juvenile delinquency. Boston: Allyn and Bacon.

Belyaeva, G.S., Komnatnaya, Y.A., Mohammed, S., Safronova, E.V., Samsonov, V.N. (2017). An analysis of the current international legal regime on the protection of the cultural heritage of indigenous peoples. Journal of History Culture and Art Research, 6(3), 1430-1440.

Cross, F. B. (1999). The relevance of law in human rights protection. International Review of Law and Economics, 19(1), 87-98. https://doi.org/10.1016/S01448188(98)00028-3

Del Carmen, R.V., \& Trulson, C.R. (2005). Juvenile justice: the system, process, and law. Stamford: Cengage Learning.

Dtinkel, F. (2008). Juvenile Justice in Germany: Between Welfare and Justice. International Handbook of Juvenile Justice. 6: 225-262.

Eshonkulov, J. (2021). Artistic interpretation of the epic creative image. International Journal of Linguistics, Literature and Culture, 7(3), 146151. https://doi.org/10.21744/ijllc.v7n3.1498

Fastelli, L., Rovai, M., \& Andreoli, M. (2018). A Spatial Integrated Database for the Enhancement of the Agricultural Custodianship Role (SIDECAR)-Some preliminary tests using Tuscany as a case-study Region. Land Use Policy, 78, 791-802. https://doi.org/10.1016/j.landusepol.2018.07.025

Finley, L.L. (2007). Encyclopedia of juvenile violence. Westpoint: Greenwood Publishing Group, $336 \mathrm{p}$.

Gavrilov, A.T. (2010). Family relations taking into account foreign gradans. Moscow: Russia, 160 p. (In Russian)

Grisso, T., Barnum, R., Fletcher, K. E., Cauffman, E., \& Peuschold, D. (2001). Massachusetts Youth Screening Instrument for mental health needs of juvenile justice youths. Journal of the American Academy of Child \& Adolescent Psychiatry, 40(5), 541-548. https://doi.org/10.1097/00004583-20010500000013

Hamner, M. (2009). Expanding the technology acceptance model to examine personal computing technology utilization in government agencies in developing countries. Government information quarterly, 26(1), 128-136. https://doi.org/10.1016/j.giq.2007.12.003

Kiss, V., Maléth, A., Tőkey, B., \& Hoffman, I. (2021). An empirical study of actions on custodianship in Hungary. International Journal of Law and Psychiatry, 78, 101719. https://doi.org/10.1016/j.ijlp.2021.101719

Lee, P. K., Lau, A. K., \& Cheng, T. C. E. (2013). Employee rights protection and financial performance. Journal of Business Research, 66(10), 1861-1869. https://doi.org/10.1016/j.jbusres.2013.02.007

Nikolaeva, Yu.V., \& Ivanova, Yu.V. (2009). On state policy in the sphere of protection of the rights and legitimate interests of minors. 6: 5-15 (In Russian)

Nugraha, D. Y., Sudirman, M. I., Rudianto, R., Ferdiansyah, D., Ismail, I., Yani, A., Utami, C., Hajid, M. K., \& Syawal, M. P. (2020). Increasing prosocial behavior through caring scout activities. International Journal of Linguistics, Literature and Culture, 6(5), 1-9. https://doi.org/10.21744/ijllc.v6n5.959

Parkhatkyzy, N., \& Apakhaev, N.Zh. (1997). Mechanisms for protecting the rights of minors: Russian and foreign experience.

Rinartha, K., Suryasa, W., \& Kartika, L. G. S. (2018). Comparative Analysis of String Similarity on Dynamic Query Suggestions. In 2018 Electrical Power, 
Electronics, Communications, Controls and Informatics Seminar (EECCIS) (pp. 399-404). IEEE.

Sammers, A. (2010). Juvenile justice in USA and Europe: yesterday, today, tomorrow.

Scholes, L., Hughes, M., Wright, M., De Massis, A., \& Kotlar, J. (2021). Family management and family guardianship: Governance effects on family firm innovation strategy. Journal of Family Business Strategy, 100389. https://doi.org/10.1016/j.jfbs.2020.100389

Sulakshin, S.S., Deeva, M.V., Bachurina, D.V., Bobrov, E.V., Kuropatkina, O.V., Netesova, M.S., \& Repin, I. V. (2012). The problem of foreign-cultural juvenile justice in modern Russia. Moscow, 144 p. (In Russian)

Tsukanov, O.V., \& Bocharov, V.A. (2017). State policy in the sphere of protection of the rights of the child in Russia. All-Russian scientific and Practical Conference (with international participation) "Fifth Legal Readings" Syktyvkar, 07-08 December 2017, Syktyvkar State University named after Pitirim Sorokin: 368-371. (In Russian)

Valdés, G., Solar, M., Astudillo, H., Iribarren, M., Concha, G., \& Visconti, M. (2011). Conception, development and implementation of an e-Government maturity model in public agencies. Government Information Quarterly, 28(2), 176-187. https://doi.org/10.1016/j.giq.2010.04.007

Verstova, M.E., \& Safonova, Yu.B. (2012). The main directions of interdepartmental cooperation in the field of protection of the rights of minors. Issues of juvenile justice. 1: 3-8 (In Russian)

Wasserman, G. A., Jensen, P. S., Ko, S. J., Cocozza, J., Trupin, E., Angold, A., ... \& Grisso, T. (2003). Mental health assessments in juvenile justice: report on the consensus conference. Journal of the American Academy of Child \& Adolescent Psychiatry, 42(7), 752-761. https:/ / doi.org/10.1097/01.CHI.0000046873.56865.4B

Wright, J. L. (2010). Guardianship for your own good: Improving the well-being of respondents and wards in the USA. International journal of law and psychiatry, 33(5-6), 350-368. https://doi.org/10.1016/j.ijlp.2010.09.007

Zharovska, I. M., Kovalchuk, V. B., Gren, N. M., Bohiv, Y. S., \& Shulhan, I. I. (2021). Age discrimination in modern global society. Linguistics and Culture Review, 5(S3), 525-538. https://doi.org/10.21744/lingcure.v5nS3.1542 